\title{
Synthesis and Antimicrobial Activities of N-(7-Substitutedthio Carbamidoquinoline-4-YI)-N, N-Diethyl-Pentane-1, 4-Diamine
}

\author{
A.K.WANJARI ${ }^{\mathrm{A}}$, D.A.PUND ${ }^{\mathrm{C}}$ A.K.BHAGWATKAR ${ }^{\mathrm{B}}$, G.G.JADHAV ${ }^{\mathrm{B}}$, \\ A-Department of Chemistry, Mahatma Fule Art, Commerce and Sitaramji Chaudhari Science \\ Mahavidyalaya, Warud. \\ B -Department of Chemistry, Govt. Institute of Science and Humanity, Amravati. skdtayade@gmail.com \\ C -Department of Chemistry, Jawaharlal Darda Institute of Engineering and Technology Yavatmal.
}

\begin{abstract}
Thioamido, quinilineo, benzamido and benzoido group containing heterocycles created their own identity and importance in pharmaceutical, medicinal, agricultural and drug sciences. Thioamido and benzamido heterocyclic compounds showed noticeable and remarkable applications in industrial, pharmaceutical, medicinal and drug chemistry. Hence taking all these facts into consideration it was thought interesting to synthesize $\mathrm{N}$ (7-substitutedthiocarbamidoquinoline-4-yl )-N, N- diethyl-pentane-1,4-diamines by interacting $N$-(7-chloroquinoline-4-yl)- $N, N$-diethyl-pentane-1,4-diamine with various thiourea in isopropanol medium .The justification and identification of the structure of these newly synthesized compounds had been established on the basis of chemical characterization, elemental analysis and through spectral data The antimicrobial activities of this compounds were screened against E. coli, S. typhi, S. abony, P. aeruginosa, B. subtilis, A. niger, and C. albicons pathogens which are hither to unknown.
\end{abstract}

\section{Keywords}

Substitutedthiocarbamides, N-(7-substitutedthiocarbamidoquinoline-4-yl)-N, N-diethylpentane-1,4-diamine and isopropanol

\section{Introduction}

Recently in this laboratory the synthetic applications of cynoguanidine and 1,3diformamido-thiocarbamide had been briefly explored ${ }^{1}$. As evident from structure of $\mathrm{N}-(7-$ substitutedthiocarbamidoquinoline-4-yl)-N,N-diethylpentane-1,4-diamine possesses Chloro, amino, methyl and ethyl reactive sides for various reactions. As a wider porgramme of this laboratory in the synthesis of nitrogen, sulphur and nitrogen and sulphur containing heteroacycles and heterocycles the interactions of cynoguanidine with various thiourea and isothiocyanates had been investigated in 
sufficient details ${ }^{2-8}$. Some of these compounds showed remarkable pharmaceutical and biological activities $^{9-12}$.

An exhaustive literature survey showed that thiocarbamido ${ }^{3-6}$ and N-(7substitutedthiocarbamidoquinoline-4-yl)-N,N-diethyl-pentane-1,4-diamine ${ }^{13-15}$ containing drugs play an important role in pharmaceutical, medicinal and drug chemistry having remarkable pharmaceutical, medicinal and biochemical applications. By considering all these facts, interactions of N-(7-chloroquinoline-4-yl)-N,N-diethyl-pentane-1,4-diamine with various thiourea in isopropanol medium were investigate to isolate yet new series of $\mathrm{N}-(7-$ substitutedthiocarbamidoquinoline-4-yl)-N,N-diethyl-pentane-1,4-diamines.

(Scheme 1) and antimicrobial activities were studied.

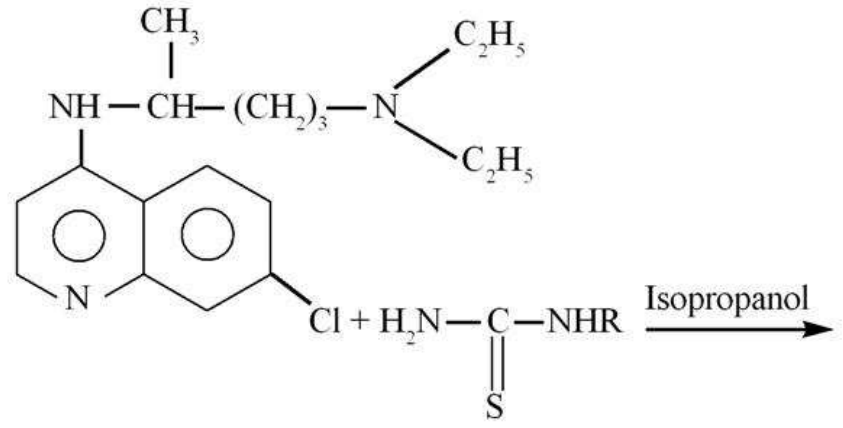

(1)
(2)

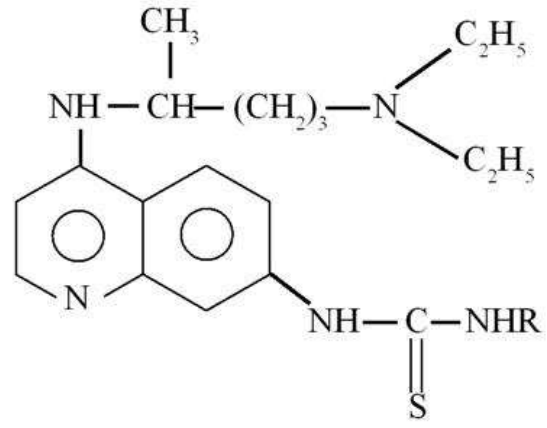

(3)

Where $\mathrm{R}=-\mathrm{H}$, -phenyl, -methyl, -ethyl, -allyl

\section{Scheme 1}

\section{Experimental}

The melting points of the all synthesized compounds were recorded using hot Paraffin bath. The carbon and hydrogen analysis were carried out on Carlo-Ebra 1106 analyzer. Nitrogen estimation was carried out on Colman-N-analyzer-29. IR spectra were recorded on Perkin Elmer Spectrometer in range $4000-400 \mathrm{~cm}^{-1}$ in $\mathrm{KBr}$ pellets. PMR spectra were recorded on Bruckner Ac $300 \mathrm{~F}$ Spectrometer with TMS as internal standard using $\mathrm{CDCl}_{3}$ and $\mathrm{DMSO}-\mathrm{d}_{6}$ as solvent. The purity of compound was checked on silica Gel-G Pellets by TLC with layer thickness of $0.3 \mathrm{~mm}$. All chemicals used were of AR-grade. 


\section{N-(7-Thiocarbamidoquinoline-4-yl)-N, N-diethyl-pentane-1, 4-diamine}

A mixture of N-(7-chloroquinoline-4-yl)-N, N-diethyl-pentane-1, 4-diamine (1) (0.1M), thiourea (2a) and isopropanol $(40 \mathrm{ml})$ was refluxed on boiling water bath for $4 \mathrm{hrs}$. During boiling suspended N-(7-chloroquinoline-4-yl)-N, N-diethyl-pentane-1, 4-diamine went into the solution and the new product was found to be gradually separated out .Which on basification with dilute ammonium hydroxide afforded crystals. It was filtered in hot condition and crystallized with aqueous ethanol to obtain (3a), yield $67.7 \%$, melting point $196^{\circ} \mathrm{C}$. (D)

\section{Properties}

It is white, crystalline solid having melting point $196{ }^{\circ} \mathrm{C}$. (D). It gave positive test for nitrogen and sulphur. Desulphurised with alkaline plumbite solution. It formed picrate, melting point $120^{0} \mathrm{C}$.

\section{Elemental analysis}

C [(found 67.4\%) calculated 68.96], H [(found 7.17\%) calculated 7.58\% ], N [(found $16.1 \%$ ) calculated 16.19$]$, S[(found 6.72\%) calculated 7.35].

\section{IR Spectra}

The IR spectra was carried out in $\mathrm{KBr}$ pellets and the important absorption can be correlated as $\left(\mathrm{cm}^{-1}\right) 3435.6$ (N-H stretching), [C-H (Ar)] stretching 3150.51638 .1 (C-N stretching), 1523.6 ( $=\mathrm{C}=\mathrm{NH}$ imino), 1199.7(C-N stretching), $991.9(\mathrm{~N}=\mathrm{C}=\mathrm{S})$.

\section{PMR Spectra}

The spectrum was carried out in $\mathrm{CDCl}_{3}$ and $\mathrm{DMSO}-\mathrm{d}_{6}$. This spectrum distinctly displayed the signals due to Ar-H, protons at $\delta 7.9525-7.9543 \mathrm{ppm}$. Ar-NH protons at $\delta$ 5.0417-5.0483 ppm, pyridino-NH at $\delta 4.2911-4.4564 \mathrm{ppm}$. $-\mathrm{CH}_{2}$ protons at $3.3386-3.8638 \mathrm{ppm}$. $-\mathrm{CH}_{3}$ protons at $1.2538 \mathrm{ppm}$.

Similarly other N-(7-substitutedthiocarbamidoquinoline-4-yl)-N, N-diethyl-pentane-1, 4diamines were synthesized by above mentioned method and are mentioned in Table No.1

Table No.1

\begin{tabular}{|c|c|c|c|c|}
\hline Sr.No. & $\begin{array}{l}\text { Expt. } \\
\text { No. }\end{array}$ & $\begin{array}{l}\text { N-(7-Substitutedthiocarbamidoquinoline-4-Yl) -N,N- } \\
\text { Diethyl-Pentane-1,4-Diamine }\end{array}$ & $\begin{array}{l}\text { Yield } \\
\%\end{array}$ & m.p. \\
\hline $3 b$ & 2 & ........................ -Phenyl............ & 67 & 171 \\
\hline $3 \mathrm{c}$ & 3 & ..Methyl ............. & 75 & 167 \\
\hline $3 d$ & 4 & ................-Ethyl...................... & 78 & 180 \\
\hline $3 e$ & 5 & ...................Allyl... & 65 & 178 \\
\hline
\end{tabular}




\section{Antimicrobial and Antifungal Activities}

The antimicrobial and antifungal activities ${ }^{16}$ of all these compounds were screened by using cupplate agar diffusion method in DMF, using standard Co-Trimazin $25 \mu \mathrm{g} / \mathrm{ml}$ against gram positive and gram negative bacteria such as E. coli, S. typhi, S. abony, P. aeruginosa, and B. subtilis. While all compounds were also screened for their antifungal activities by using standard Greseofulvin $(10 \mu \mathrm{g} / \mathrm{ml})$ against A. niger and C. albicans.

\section{Cup-plate method}

A medium used throughout the experiment was HI-Media (India make) having composition of Pepton - 5gm/lit., NaCl -5gm/lit, Yeast extract -1.5gm/lit, Agar powder -20gm/lit, $\mathrm{p}^{\mathrm{H}}-7.4 \pm 0.1$

The medium for antibacterial and antifungal activities were prepared $[\mathrm{N}$-agar for bacterial and Sabourands dextrose agar for fungi] by dissolving 26 gms of ingredients in one liter of distilled water and sterilized in autoclave at $121{ }^{\circ} \mathrm{C}$ at $15 \mathrm{Ibs} /$ inch pressure in an autoclave for 154 minutes. Then microbes were inoculated with requisite quantity to the medium at temperature $40-50^{\circ} \mathrm{C}$ and immediately poured the inoculate medium in to sterilized Petri dishes to give a depth of 3-4 mm of uniform thickness. After solidification the well or holes were prepared by well borer. The dimethylformamide solution of the compound was added in sufficient amount to fill the well. Then it was kept at room temperature for $4 \mathrm{~h}$, as a pre-incubation and then plates of bacteria were inoculated for $18-24 \mathrm{hrs}$, at $36-38^{\circ} \mathrm{C}$ and all plates fungi were inoculated $48 \mathrm{hrs}$ at $20-25{ }^{\circ} \mathrm{C}$. After the period of inoculation, zones of inhibition were recorded around the wells. The results are cited in Table No.2

\section{Table No.2}

\begin{tabular}{|l|l|l|l|l|l|l|l|}
\hline $\begin{array}{l}\text { Comp. } \\
\text { No }\end{array}$ & $\begin{array}{l}\text { S.typhi } \\
\mathbf{( m m})\end{array}$ & $\begin{array}{l}\text { E.coli } \\
\mathbf{( m m})\end{array}$ & $\begin{array}{l}\text { S. abony } \\
\mathbf{( m m}\end{array}$ & $\begin{array}{l}\text { P.aeruginosa } \\
\mathbf{( m m})\end{array}$ & $\begin{array}{l}\text { B. subtilis } \\
(\mathbf{m m})\end{array}$ & $\begin{array}{l}\text { A. niger } \\
\mathbf{( m m}\end{array}$ & $\begin{array}{l}\text { C. albicans } \\
(\mathbf{m m})\end{array}$ \\
\hline 3a & 1.2 & 1.0 & 1.2 & 0.8 & 0.4 & -- & -- \\
\hline 3b & 1.8 & 1.6 & 1.8 & 1.1 & 1.2 & 0.3 & -- \\
\hline 3c & 1.4 & 1.1 & 1.1 & 0.7 & 0.6 & -- & -- \\
\hline 3d & 1.1 & 0.9 & 0.6 & 0.6 & 0.6 & 0.1 & -- \\
\hline 3e & 1.6 & 1.2 & 1.3 & 1.0 & 0.8 & -- & -- \\
\hline
\end{tabular}

All the seven organisms studied are human pathogens from the results it is clear that all the synthesized compounds showed remarkable and considerable antimicrobial activities. These thiocarbamides showed highly activity against E. coli, S. typhi, S. abony, P. aeruginosa, B. subtilis, While less active against A. niger and C. albicans. Hence study of these compounds is required in biochemical 
and medicinal directions. From the above data it is concluded that this compounds showed remarkable antibacterial activity that antifungal activity. S. typhi causes typhoid while E. coli causes diarrhoea and S. abony causes pus formation. It is observed from literature survey of medicinal sciences that in the last two decades the patients of typhoid and diarrhoea throughout the world are common. Lower drugs of typhoid are now totally rejected and higher drugs are now given to the patients. As newly synthesized thiocarbamides showed remarkable and considerable activities so these compounds can be used as alternative for the treatment of diseases caused by the above mentioned pathogens only if they do not have toxic and other side effects after the details study. The potency of the drug is increased due to substitution of thiocarbamido moiety on the previous drug.

\section{References}

1. D. T. Tayade, Ph.D Thesis Amravati University, Amravati, 1996.

2. O. V. Rudnitskaya, E. K. Kultyshkina, I. V. Linko, V. S. Sergienko, C. G. Aleksandrov, Russian J of Co-ordination Chem., 2010,36 137-142.

3. D.T. Tayade, R.A. Bhagwatkar, R.C. Panpalia, International Journal of Chemistry Canada, 2010, 2 (2), 41-43.

4. R.A. Bhagwatkar, D.T. Tayade, Orbital Elec. J. Chem., Campo Grande Brazil, 2011, 3(1), 5356 ,

5. D.T.Tayade, D.A. Pund, R.A. Bhagwatkar, D.B. Rathod, N.A. Bhagwatkar, International Journal of Chemistry Canada , 2011, 3 (1), 36-41.

6. D.T.Tayade, M. R. Raghuwanshi, R.A. Bhagwatkar , International Journal of Chemistry Canada, 2011, 3(2), 74-78.

7. P.K. Shrivastava, "Bases related with thiourea”, Ph.D. Thesis, B.H.U, 1964.

8. L.G. Dover, A. Alahari, P. Gratraud, J. M. Gomes, V. Bhowruth., R. C. Reynolds, G. S. Besra, Ln. Kremer, Antimicrobial Age ts and Chemotheraphy, 2007, 519(3), 1055-1063.

9. M.G. Paranjpe, J Indian Chem. Soc, 1966, 4245.

10. C.P. Joshua. “Chemistry of Hector’s base”, Ph.D., Thesis, B.H.U, 1962.

11. P.P. Deohate, B.N. Berad, Indian J.Chem, 2005, 44B, 638-642.

12. www.drugs.com

13. J.S.Waghmare Ph.D Thesis, S.G.B. Amravati University, Amravati 2007

14. R.C. Panpalia Ph.D Thesis S.G.B. Amravati University, Amravati 2005

15. M.R. Raghuwanshi Ph.D Thesis S.G.B. Amravati University, Amravati 2007 